\title{
The Effectiveness of California Tri-Pull Kinesiotaping in Reducing Glenohumeral Shoulder Subluxation After Stroke: $A B$ design
}

\section{California Tri-Pull Kinezyo bantlamanın İnme Sonrası Glenohumeral Omuz Subluksasyonunu Azaltmadaki Etkinliği: AB tasarımı}

\author{
Sanem Aslıhan Aykan1, ๑Dudu Çelik Tam², ๑Tuğba Özsoy-Ünübol1, @Hilmi Kılac1, ๑Halil Uçan³, \\ (D) Meltem Aras ${ }^{3}$
}

'Department of Physical Medicine and Treatment, Sultan Abdulhamid Han Training and Research Hospital, İstanbul, Turkey 2Department of Physical Medicine and Treatment, Gülhane Training and Research Hospital, Ankara,Turkey ${ }^{3}$ Department of Physical Medicine and Treatment, Ankara City Hospital, Ankara, Turkey

\begin{abstract}
Aim: Glenohumeral subluxation (GHS) is a common complication of hemiplegia after stroke. The inferior dislocation is the most frequently encountered GHS in stroke patients, and it is important to choose the proper treatment to promote better stability after repositioning the humerus. To evaluate the short-term effect of the California tri-pull taping method with elastic kinesiotape (CTPK) on pain, recovery of movement and daily life activities in Turkish hemiplegic patients.

Material and Method: Fourteen hemiplegic participants with GHS involved in this study All patients had at least three weeks of conventional inpatient neurorehabilitation. During the rehabilitation program, all patients with GHS had kinesiotaping four times with five-day interval for three weeks. Outcome measures were a verbal descriptive pain scale (VPDS), the Katz index of independence in activities of daily living, and a radiologic and physical examination.

Results: No significant difference was found between the participants regarding sex, age, duration of stroke, and VPDS scores ( $p>0.05)$. Motor recovery stages were improved after CTPK, pain scores decreased, and Katz index increased with the treatment. Passive ROMs of the shoulder were significantly increased. Subluxation was found by palpation to be improved but did not show any radiographic changes.

Conclusion: CTPK can reduce pain and improve quality of life, passive ROM and subluxation. Our findings suggest that radiological grading of subluxation is not sensitive enough and should not be used to evaluate improvement of inferior subluxation in stroke patients.
\end{abstract}

Keywords: stroke, shoulder, subluxation, kinesiotaping

\section{Öz}

Amaç: Glenohumeral subluksasyon (GHS), inme sonrası hemiplejinin sık görülen bir komplikasyonudur. İnme hastalarında omuzun inferiora sublukse olması en sık karşılaşılan GHS'dir ve humerusu yeniden konumlandırdıktan sonra daha iyi stabiliteyi sağlamak için uygun tedaviyi seçmek önemlidir. Amacımız, hemiplejik GHS hastalarında, California tripull bantlama yöntemi ile uygulanan elastik kinezyo bantlama (CTPK) ile hastalardaki ağrı, hareket geri kazanımı ve günlük yaşam aktiviteleri üzerine kısa süreli etkisini değerlendirmektir.

Gereç ve Yöntem: Bu çalışmaya katılan GHS'li on dört hemiplejik hastaya haftada en az üç kez geleneksel yatarak nörorehabilitasyon uygulandı. Rehabilitasyon programı sırasında GHS'li tüm hastalara üç hafta boyunca beş gün arayla dört kez kinezyo bantlama yapıldı. Hastalar, sözel tanımlayıcı ağrı skalası (VPDS), günlük yaşam aktivitelerinde Katz bağımsızlık indeksi ve radyolojik görüntüleme ve fizik muayene ile değerlendirildi.

Bulgular: Katılımcılar arasında cinsiyet, yaş, inme süresi ve VPDS puanları açııından anlamlı fark bulunamadı ( $p>0,05)$. Tedavi ile CTPK sonrası motor iyileşme evreleri düzeldi, ağrı skorları azaldı ve Katz indeksi arttı. Omuzun pasif ROM'ları Önemli ölçüde arttı. Subluksasyonun palpasyonla düzeldiği bulundu, ancak herhangi bir radyografik değişiklik gözlenmedi.

Sonuç: CTPK ağrıyı azaltabilir ve yaşam kalitesini, pasif ROM'u ve subluksasyonu iyileştirebilir. Bulgularımız subluksasyonun radyolojik derecelendirmesinin yeterince hassas olmadığını ve inme hastalarında inferior subluksasyonun iyileşmesini değerlendirmek için kullanılmaması gerektiğini göstermektedir.

Anahtar Kelimeler: inme, omuz, subluksasyon, kinezyo bantlama

Corresponding (iletişim): Sanem Aslıhan Aykan, 1Department of Physical Medicine and Treatment, Sultan Abdulhamid Han Training and Research Hospital, Turkey

E-mail (E-posta): sanemaykan@hotmail.com

Received (Geliş Tarihi): 05.08.2021 Accepted (Kabul Tarihi): 29.09.2021 


\section{INTRODUCTION}

Glenohumeral subluxation (GHS) is a common complication of hemiplegia after stroke with a high prevalence of $46-81 \%$. ${ }^{[1-3]}$ Complex regional pain syndrome and rotator cuff injuries can occur as a result of GHS, and the associated severe pain restricts upper limb movement and slows the rehabilitation process. ${ }^{[4,5]}$ Thus, the management of GHS is a key element for rehabilitating the stroke patient.

Slings, strapping, positioning and electrical stimulation are widely used for the prevention and treatment of GHS.[6 7] The inferior dislocation is the most frequently encountered GHS in stroke patients, and it is important to choose the proper treatment to promote better stability by focusing on correct positioning of the humerus. ${ }^{[8]}$ Studies evaluating the effect of taping on GHS reported contradictory results from improvement in shoulder range of motion (ROM), and reduction in pain and disability, ${ }^{[9-11]}$ to no effect on pain and disability. ${ }^{[12]}$ This appeared to result from the use of different taping techniques. ${ }^{[9-12]}$ Hayner developed the California tripull taping (CTPT) method to specifically treat subluxation in stroke patients, and showed its effectiveness in reducing subluxation, and improving activities of daily life and active ROM, but without changing the severity of shoulder pain. [13] In a randomized controlled clinical trial, CTPT was shown to reduce pain and improve flexion and upper extremity function. ${ }^{[14]}$ Since there had been no study of the CTPT method with kinesiotaping in one-year onset hemiplegic patients with radiographic follow-up, we aimed to evaluate its effectiveness in reducing pain and improving ROM and daily life activities in Turkish hemiplegic patients.

\section{MATERIAL AND METHOD}

\section{Research Type}

The study reported here is a modification of a previously described quasi-experimental, single-subject $A B$ design. ${ }^{[13]}$ with fourteen participants. In the $A B$ design, the patients act as their own controls because of the inability to exclude the placebo effect of kinesiotaping over conventional neurorehabilitation treatment.

\section{Participants}

Twenty-five hemiplegic patients with GHS admitted to Physical Medicine and Rehabilitation Clinics at the University of Health Sciences, Ankara Physical Medicine and Rehabilitation Training and Research Hospital and Sultan Abdulhamid Han Training and Research Hospital were screened for the study. Six were excluded, and 2 refused to participate; thus, 18 patients diagnosed with shoulder subluxation participated in this study. Four patients dropped out from study. Only one patient ceased the treatment due to personal reasons. One patient received intraarticular injection on day 2 and two of the patients removed their kinesiotape after having shower. Therefore only 14 patients included in statistical analysis (Figure 1). Inclusion criteria were (1) 18 to 90 years of age, (2) stroke onset within one year, (3) shoulder subluxation in the involved upper extremity and (4) being oriented and cooperative. Exclusion criteria of the study were (1) global aphasia, (2) malignancy, (3) previous shoulder pain or surgery, (4) other neuromuscular disorders and (5) severe cardiopulmonary disease that affects daily life activities. The treatment was ceased if a surgery or intervention was planned to effected shoulder or extremity or if the patient did not want to continue to the study (Figure 2).



Figure 1. Flow chart for study

\begin{tabular}{|c|c|c|}
\hline Inclusion criteria & Exclusion criteria & Ending criteria \\
\hline $\begin{array}{l}\text { - } 18 \text { to } 90 \text { years of age } \\
\text { - Stroke onset within one year } \\
\text { - Shoulder subluxation in the } \\
\text { involved upper extremity } \\
\text { - Being oriented and cooperative }\end{array}$ & $\begin{array}{l}\text { - Global aphasia } \\
\text { - Malignancy } \\
\text { - Previous shoulder pain or } \\
\text { surgery } \\
\text { - Other neuromuscular disorders } \\
\text { - Severe cardiopulmonary disease } \\
\text { that affects daily life activities }\end{array}$ & $\begin{array}{l}\text { - Person does not want to continue } \\
\text { treatment any longer } \\
\text { - Misuse of kinesiotaping such as } \\
\text { removing the tape before the } \\
\text { next session } \\
\text { - Increase in pain } \\
\text { - Adverse effects of kinesoitaping } \\
\text { - Recieving any other treatment } \\
\text { to effected shoulder or extremity }\end{array}$ \\
\hline
\end{tabular}

Figure 2. Eligibility criteria for the study

All procedures performed in studies involving human participants were performed in accordance with the ethical standards of the institutional and/or national research committee and with the 1964 Helsinki Declaration and its later amendments or comparable ethical standards. The study was approved by local ethic committee of Ankara Physical Therapy and Rehabilitation Training and Research Hospital. An informed consent was taken from all participants who wish to participate the study. This study is registered to clinicaltrials. org (ID: NCT04468750). 


\section{Intervention}

All patients had at least three weeks of inpatient conventional neurorehabilitation. During the rehabilitation program, all patients with GHS had kinesiotaping four times with five day interval for three weeks. Kinesiotape (Nasara, Korea) was applied using the California tri-pull taping (CTPT) method with a $100 \%$ stretch. Three strips $(5.0 \mathrm{~cm}$ width) were prepared, and all strips were applied starting from $3.5 \mathrm{~cm}$ below the deltoid tuberosity to the middle of the scapular spine, and $5 \mathrm{~cm}$ above to the top of the glenoid fossa between the clavicle and the spine of the scapula; and, also on the front of the humeral head, over the coracoid process to $3.5 \mathrm{~cm}$ above the clavicle as described in the Hayner study. ${ }^{[13]}$

In the conventional neurorehabilitation program, all patients received one hour of inpatient treatment five days per week for three weeks. Each day's 60-minute therapy session consisted of active and passive range of motions (ROM), neuromuscular re-education, upper extremity functional activities, balancing, sitting, standing, and transferring and ambulation education.

All patients were evaluated before and after the treatment. Pain, ROM, subluxation, Brunnstrom motor recovery stage and daily life activities were evaluated.

\section{Primary Outcome Measures}

Subluxation: Subluxation was measured by physical examination and radiography. For the physical exam, a clinician measured the gap between the acromion and the humeral head with the fingerbreadth at the distal interphalangeal joint of the right index and middle fingers. The anterio-posterior shoulder X-ray was taken in an erect position, and subluxation was evaluated by Van Langenberghe's five point classification. [3,15] Higher point indicates higher subluxation gap.

Pain: Pain with motion was measured by a verbal descriptive pain scale (VDPS). The VDPS was developed by Melzack and Katz and is composed of words such as "mild" (level 1) to "very severe pain" (level 5). ${ }^{[16]}$ The scale has been used with Turkish people. ${ }^{[17]}$ and is preferred for patients who cannot rate their pain by numbers because of cognitive issues. ${ }^{[18]}$

\section{Secondary Outcome Measures}

Range of motion: Passive shoulder ROM (flexion and abduction) was measured with a goniometer. Passive shoulder ROM was used in order to exclude patient's neurological status (motor recovery status).

Motor recovery stage: The motor recovery stage of the subjects was assessed with the Brunnstrom (BRS) index for hand and arm. BRS was a staging system aim to describe the sequence of motor recovery after stroke based on synergy patterns. The BRS scored on a 6-level Likert-type scale (level I to VI), can be assessed in three regions; arm, hand and lower extremity. 3 items. Higher levels indicates better motor function. ${ }^{[19,20]}$

Daily life activities: Daily life activities were evaluated using the Katz index of independence in activities of daily living, which evaluates the patients in bathing, dressing, toileting, transferring, continence, and eating. Activities were scored as zero or one with the total score ranging from zero to six. ${ }^{[21]}$

\section{Statistics}

Statistical Package for the Social Sciences 20.0 was used for performing the statistical analysis. Descriptive statistics (frequency, mean, percentage and standard deviation) were used for analyzing the sociodemographic and clinical features. Categorical parameters were assessed through Fisher's exact test. For two independent groups, the Mann-Whitney $U$ test was used, whereas the Marginal Homogenity test was used for more than two independent categorical groups. A posthoc Bonferroni analysis was performed to assess the statistical significance. The Spearman correlation was used to analyze the relationship of quantitative data to each other. The results were analyzed using a 95\% confidence interval and a significance level of $\mathrm{p}<0.05$.

\section{RESULTS}

The patients' demographics are summarized in Table 1, and no significant differences were found with regard to sex, age, duration of stroke, and VPDS ( $p>0.05$ ). Each stroke patient had an inferior subluxation of the shoulder diagnosed by radiography, but only four (28.6\%) were on analgesics. Most did not receive any treatment that was not indicated in the methods section, and no patient reported discomfort from the CTPK treatment.

\begin{tabular}{lc}
\hline Table 1. Demographics of patients & $\mathbf{n}$ \\
\hline $\begin{array}{lc}\text { Sex } \\
\text { Female }\end{array}$ & $5(35.7 \%)$ \\
Male & $9(64.3 \%)$ \\
Coexistance of disease & \\
Diabetes mellitus & $8(57.14 \%)$ \\
Hypertension & $11(78.57 \%)$ \\
Hyperlipidemia & $3(21.43 \%)$ \\
Coronary artery disease & $6(42.86 \%)$ \\
Age (mean \pm SD) & $55.9 \pm 14.3 \mathrm{y}(26-76 \mathrm{y})$ \\
Duration of stroke (mean \pm SD) & $7.7 \pm 4.5 \mathrm{mo} .(1-12 \mathrm{mo})$. \\
\hline mo: months, $\mathrm{n}$ : number, SD: standard deviation, y: year &
\end{tabular}

The average reduction in the amount of subluxation measured by palpation was 0.54 fingerbreadth on day 21 $(p=0.003)$. The reduction from baseline was 0.5 in four patients, 1 in two patients and 1.5 fingerbreadths in two patients. Four patients did not reveal any change in subluxation with treatment (Figure 3). However, there was no change in radiographic Van Langenberghe classification between the baseline and posttreatment phase $(p=1)$. Most of the patients had either grade 1, V shaped widening (35.7\%), or grade 2, moderate subluxation (50\%), which remain unchanged after the treatment (Table 2).

The pain experienced at posttreatment was mostly during motion and indicated a decreasing trend $(p<0.001)$. Most patients who reported "moderate" pain said that it was now "mild" and "severe" pain had become"moderate" (Table 2). 


\begin{tabular}{|c|c|c|c|c|c|c|c|c|}
\hline \multirow[b]{2}{*}{ Brunstrumm Levels } & \multirow[t]{2}{*}{ Time } & \multicolumn{6}{|c|}{ Levels/ Classification } & \multirow[t]{2}{*}{$\mathbf{P}$} \\
\hline & & I & II & III & IV & V & VI & \\
\hline \multirow{2}{*}{ Hand } & Baseline & 0 & 9 & 3 & 0 & 1 & 1 & \multirow{2}{*}{$0.014^{*}$} \\
\hline & Day 21 & 0 & 5 & 5 & 2 & 1 & 1 & \\
\hline \multirow{2}{*}{ Arm } & Baseline & 2 & 8 & 1 & 1 & 1 & 1 & \multirow{2}{*}{$0.025^{*}$} \\
\hline & Day 21 & 1 & 6 & 3 & 2 & 1 & 1 & \\
\hline \multicolumn{2}{|c|}{ Verbal Pain Descriptive Scale } & I & II & III & IV & V & & \multirow{3}{*}{$0.001^{*}$} \\
\hline \multirow{3}{*}{\multicolumn{2}{|c|}{$\begin{array}{r}\text { Baseline } \\
\text { Day } 21 \\
\text { Van Langenberghe's Classification }\end{array}$}} & 0 & 8 & 6 & 0 & 0 & & \\
\hline & & 8 & 5 & 1 & 0 & 0 & & \\
\hline & & 0 & 1 & II & III & IV & & \multirow{3}{*}{$1 *$} \\
\hline & Baseline & 0 & 6 & 7 & 1 & 0 & & \\
\hline & Day 21 & 0 & 6 & 7 & 1 & 0 & & \\
\hline
\end{tabular}

The motor recovery stage of the subjects was assessed with the Brunnstrom index for hand and arm. The median values of the Brunnstrom recovery stage of the hand and arm were significantly increased between the baseline and day 21 (Table 2). The median value of the Brunnstrom of the hand at baseline was 2 and at posttreatment, $3(p=0.014)$. The median value of the Brunnstrom of the arm at baseline was 2 and at posttreatment, $2.5(p=0.025)$. Even though the change of the Brunnstrom of the arm did not reach significant, the decreasing trend was observed.

The median ADL function score (Katz index) was 2 at baseline and 3 at posttreatment and the difference was statistically significant ( $p=0.028$ ) (Figure 4A).

Goniometric measurement of passive ROM indicated a statistically significant increase in ROM angle of both shoulder abduction and flexion after three weeks ( $p=0.008$ and $p=0.004$, respectively) (Figure 4B). Initial baseline of shoulder abduction ROM (mean \pm SD) was $96.5 \pm 4.25$ degrees (ranging



Figure 3. Estimation and difference plot of subluxation gap. B: Baseline D: Day

from 60 to 120 degrees) while shoulder flexion (mean \pm SD) was $91.5 \pm 6.28$ degrees (ranging from 45 to 120 degrees). After treatment, both abduction and flexion ROM (median) were 120 degrees, ranging from 80 to 135 degrees and 70 to 120 degrees respectively.

\section{DISCUSSION}

Our results showed that CTPT treatment of this group of poststroke GHS patients, improved subluxation, functional motor recovery and shoulder ROM, and reduced pain. Hayner.[13] and Chatterjee et al. ${ }^{[14]}$ used the CTPT method with two types of tape: cotton undercover tape and rigid strapping tape. Hayner found no significant difference in pain, but Chatterjee et al. reported significant pain reduction. In our study, CTPT method executed with elastic kinesiotape. Even though, the results of kinesiotaping with different methods on shoulder pain are conflicting for both hemiplegic and non-hemiplegic patients, ${ }^{[9,11,12,22-25]}$ the patients in our study had significant

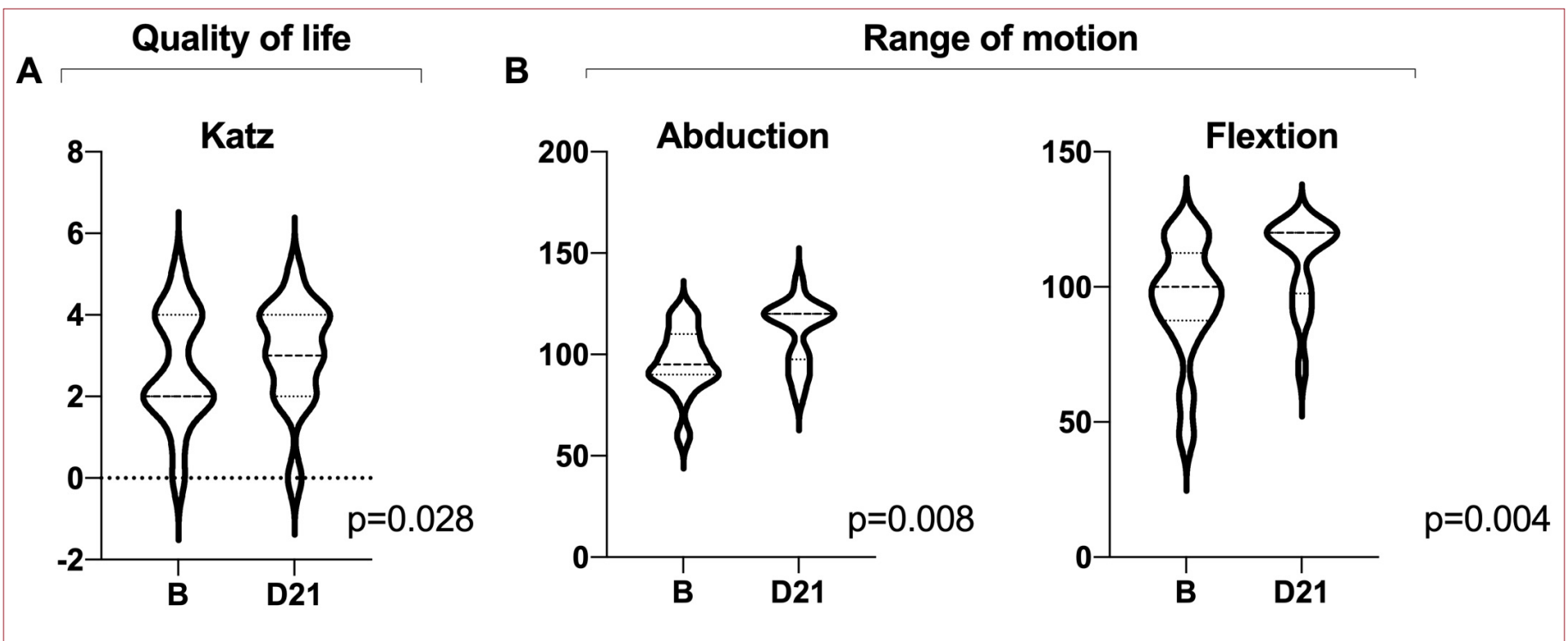

Figure 4. Violin plot of Katz and range of motion. B: Baseline D: Day 
reductions in pain scores and significant improvement in painfree ROM. Although the mechanism of action of kinesiotape is not clear, it is superior to non-stretchable tape in being inexpensive, flexible, easily stretched and applied, and it has been found effective for hemiplegic shoulder pain. ${ }^{[2]}$

In this study, we evaluated the effects of kinesiotaping on subluxation by physical examination (palpation) and radiography and only found significant improvement by palpation. Since CTPT helps to pull the humeral head upwards and improves stabilization and pain-free ROM, subluxation detected by palpation was expected to be improved. Studies using this method showed palpable reduction in acromiohumeral distance but none of them used radiography to grade the degree of subluxation. ${ }^{[8,13,14]}$ One of our aim in this study was to determine whether radiography would provide the same results as palpation. Other tests of kinesiotaping designed to alleviate hemiplegic shoulder pain used different taping methods that did not pull the humerus upwards and they did not show significant reduction in subluxation using ultrasonography imaging. ${ }^{[9,11]}$

Chatterjee at al. evaluated active flexion only, while Hayner evaluated active flexion and abduction. They both found significant improvement in shoulder ROM. ${ }^{[13,14]}$ Peters et al. used a similar taping method on a single case and also showed significant improvement in passive abduction and flexion; however, his subject's upper extremity was nonfunctional before and after treatment so active ROM could not be evaluated. ${ }^{[8]}$ To reduce the effect of motor recovery, we chose to evaluate passive abduction and flexion in our study, and significant improvement was seen in passive ROM as well. Kalichman et al. did not measure a positive effect of kinesiotape on active and passive shoulder abduction, but other studies reported benefits from kinesiotaping on passive shoulder ROM. ${ }^{[9,11,12]}$ Investigations of the effect of kinesiotape on shoulder pain in non-hemiplegic patients also showed significant improvement in pain-free shoulder abduction. ${ }^{[22]}$ Our data confirmed that CTPK could improve upper extremity function as evaluated by Brunnstrom motor recovery stage and the Katz index of independence in activities of daily living. Hayner, who developed the CTPT method, assessed daily life activities using the Katz index and found significant improvement as well. ${ }^{[13]}$ Other researchers using different taping methods and different scales such as the Barthel index, the modified Barthel index, the Fugl-Meyer upper extremity motor assessment (FMA) and the shoulder pain and disability index, showed similar results..$^{[8,9,11,14]}$ Kalichman et al. evaluated patients' upper extremity functions with FMA and 'box \& blocks', and found no improvement and no change in pain and ROM. ${ }^{[12]}$ In our study, all patients had inpatient neurorehabilitation sessions in addition to kinesiotaping and the improvement in Brunnstrom motor recovery stage and the Katz index of activities may have been positively affected by the physical therapy. However, reduction in hand pain and improvement of passive ROM can lead to improvement in upper extremity function. Because the patients were one-year onset hemiplegic patients, it was deemed unethical to test the effect of kinesiotaping without neurorehabilitation.

One limitation in the design of our study is the lack of a control group; but the quasi-experimental $A B$ method with inclusion of a baseline measurement followed by the intervention for each patient should reduce the statistical unevenness.

\section{CONCLUSIONS}

Our application of the CTPK method for hemiplegic patients who have inferior shoulder dislocation had positive effects on pain, shoulder ROM and function. X-ray evaluation of the effects on subluxation was unsuitable compared to the simple physical method of palpation. The CTPK technique is easy to apply, time- and cost-effective, and can be used as a supplementary treatment to a conventional neurorehabilitation program by occupational therapist without radiological evaluation. Further investigations with randomized, placebo-controlled designs are needed to confirm efficacy of the kinesiotaping method..

\section{ETHICAL DECLARATIONS}

Ethics Committee Approval: The study was approved by local ethic committee of Ankara Physical Therapy and Rehabilitation Training and Research Hospital. This study is registered to clinicaltrials.org (ID: NCT04468750).

Informed Consent: All patients signed the free and informed consent form.

Referee Evaluation Process: Externally peer-reviewed.

Conflict of Interest Statement: The authors have no conflicts of interest to declare.

Financial Disclosure: The authors declared that this study has received no financial support.

Author Contributions: All of the authors declare that they have all participated in the design, execution, and analysis of the paper, and that they have approved the final version.

Note: This study was presented as poster in INEREM 2015 and National Physical Medicine and Rehabilitation Congress 2015.

\section{REFERENCES}

1. Najenson T. Rotator cuff injury in shoulder joints of hemiplegic patients. Scand J Rehabil Med 1971;3:131-37

2. Smith R, Cruikshank J, Dunbar S, Akhtar A. Malalignment of the shoulder after stroke. Br Med J 1982;284(6324):1224-26

3. Van Langenberghe HV, Hogan BM. Degree of pain and grade of subluxation in the painful hemiplegic shoulder. Scand J Rehabil Med 1988;20(4):161-6

4. Stolzenberg D, Siu G, Cruz E. Current and future interventions for glenohumeral subluxation in hemiplegia secondary to stroke. Top Stroke Rehabil 2012;19(5):444-56

5. Kumar P, Swinkels A. A critical review of shoulder subluxation and its association with other post-stroke complications. Phys Ther Rev 2009;14(1):13-25

6. Paci M, Nannetti L, Rinaldi LA. Glenohumeral subluxation in hemiplegia: An overview. JRRD 2005;42(4):557 
7. Griffin C. Management of the hemiplegic shoulder complex. Top Stroke Rehabil 2014;21(4):316-18

8. Peters SB, Lee GP. Functional impact of shoulder taping in the hemiplegic upper extremity. Occup Ther Health Care 2003;17(2):35-46

9. Huang YC, Chang KH, Liou T-H, Cheng CW, Lin LF, Huang SW. Effects of Kinesio taping for stroke patients with hemiplegic shoulder pain: a double-blind, randomized, placebo-controlled study. J Rehabil Med 2017;49(3):208-15

10. Pillastrini $P$, Rocchi G, Deserri $D$, et al. Effectiveness of neuromuscular taping on painful hemiplegic shoulder: a randomised clinical trial. Disabil 2016;38(16):1603-09

11. Huang Y-C, Leong C-P, Wang L, et al. Effect of kinesiology taping on hemiplegic shoulder pain and functional outcomes in subacute stroke patients: a randomized controlled study. Eur J Phys Rehabil Med 2016;52(6):774-81

12. Kalichman L, Frenkel-Toledo S, Vered E, et al. Effect of kinesio tape application on hemiplegic shoulder pain and motor ability: a pilot study. Int J Rehabil Res 2016;39(3):272-76

13. Hayner KA. Effectiveness of the California Tri-Pull Taping method for shoulder subluxation poststroke: A single-subject ABA design. Am J Occup Ther 2012;66(6):727-36

14. Chatterjee S, Hayner KA, Arumugam N, et al. The California tri-pull taping method in the treatment of shoulder subluxation after stroke: a randomized clinical trial. N Am J Med Sci 2016;8(4):175

15. Snels IA, Beckerman H, ten Kate JJ, Lankhorst GJ, Bouter LM. Measuring subluxation of the hemiplegic shoulder: reliability of a method. Neurorehabil Neural Repair 2001;15(3):249-54

16. Katz J, Melzack R. Measurement of pain. Surg Clin North Am 1999;79(2):231-52.

17. Yazici Sayin Y, Akyolcu N. Comparison of Pain Scale Preferences and Pain Intensity According to Pain Scales among Turkish Patients: A Descriptive Study. Pain Manag Nurs 2014;15(1):156-64

18. Herr KA, Spratt K, Mobily PR, Richardson G. Pain intensity assessment in older adults: use of experimental pain to compare psychometric properties and usability of selected pain scales with younger adults. Clin J Pain 2004;20(4):207-19

19. Brunnstrom S. Motor testing procedures in hemiplegia: based on sequential recovery stages. Phys Ther 1966;46(4):357-75

20. Huang CY, Lin GH, Huang YJ, et al. Improving the utility of the Brunnstrom recovery stages in patients with stroke: Validation and quantification. Medicine 2016;95(31):e4508

21. Katz S, Downs TD, Cash HR, Grotz RC. Progress in development of the index of ADL. Gerontologist 1970;10(1):20-30

22. Thelen MD, Dauber JA, Stoneman PD. The clinical efficacy of kinesio tape for shoulder pain: a randomized, double-blinded, clinical trial. J Orthop Sports 2008;38(7):389-95

23. Şimşek H, Balki S, Keklik SS, Öztürk H, Elden H. Does Kinesio taping in addition to exercise therapy improve the outcomes in subacromial impingement syndrome? A randomized, double-blind, controlled clinical trial. Acta Orthop Traumatol Turc 2013;47(2):104-10

24. Montalvo AM, Cara EL, Myer GD. Effect of kinesiology taping on pain in individuals with musculoskeletal injuries: systematic review and metaanalysis. Phys Sportsmed 2014;42(2):48-57

25. Kalron A, Bar-Sela S. A systematic review of the effectiveness of Kinesio Taping--fact or fashion? Eur J Phys Rehabil Med 2013;49(5):699-709 